УДК 336.741

\title{
ОСОБЕННОСТИ РАЗВИТИЯ РЫНКА ЭЛЕКТРОННЫХ БАНКОВСКИХ ПРОДУКТОВ И УСЛУГ В РЕСПУБЛИКЕ БЕЛАРУСЬ
}

\author{
Е.С. КСЕНЗОВ \\ магистрант экономического факультета \\ Белорусского государственного университета, г. Минск
}

\begin{abstract}
Аннотация
Инновачии в банковской сфере, прогресс в информащионных технологиях тесно связаны с инновачиями в мировом финансовом секторе. Этот прочесс неизбежен для всех банков в различных странах, в том числе и в Республике Беларусь. Темпы развития электронной коммериии в нашей стране невелики, однако как банки, так и их регулятор заинтересованы в совершенствовании организаџии электронных банковских услуг. Стратегия банковского сообщества республики направлена, прежде всего, на повышение качества и увеличение количества электронных услуг, которые стимулируют рост безналичных расчетов. Данный эффект призван усилить влияние монетарных мер Национального банка, упростить управление банков своей ликвидностью, а также поспособствовать экономическому росту, который имеет прямую взаимосвязь с ростом безналичных расчетов.
\end{abstract}

Ключевые слова: банковская услуга, банковский продукт, рынок банковских услуг, электронные банковские услуги.

Abstract

The banking sector innovation andinformation technologies progress are closely linked to innovation in the global financial sector. This process is inevitable for all banks in various countries, including the Republic of Belarus. The pace of development of e-commerce in our country is small, but banks and their regulator are interested in improving the organization of electronic banking services. Belarus banking community strategy is aimed primarily at improving the quality and increasing the number of electronic services, which stimulate the growth of non-cash payments. This effect is intended to enhance the impact of monetary measures of the National Bank, simplify the management of its liquidity, as well as contribute to economic growth, which has a direct relationship with the growth of non-cash payments.

Key words: banking services, banking products, market of banking services, electronic banking services.

\section{ВВЕДЕНИЕ}

Главной особенностью электронных банковских услуг является то, что их использование требует от потребителей определенного культурного и образовательного уровня. Поэтому банковскому сообществу необходимо найти пути решения проблемы невысокой финансовой грамотности, а банкам - выработать стратегию с учетом данного фактора.

В экономической литературе существуют разные подходы к трактовке понятия «банковская услуга». Каждый из них имеет право на существование, несмотря на возникшие противоречия. Дополняя друг друга производственным, функциональным, маркетинговым, правовым, институциональным анализами, они позволяют преодолеть односторонний подход, многогранно исследовать сущность и природу банковской услуги.

При обзоре зарубежной и отечественной экономической литературы можно выделить несколько подходов к определению данной категории: функциональный, маркетинговый и институциональный. Большинство российских и отечественных авторов придержи- 
ваются функционального подхода к определению данной категории. Данный подход рассматривает банковскую услугу как одну или несколько операций банка, удовлетворяющих определенные потребности клиента. Причем многие авторы смешивают понятия услуги и операции, хотя это два взаимосвязанных, но индивидуальных понятия.

Определения, обозначенные в трудах Г.Н. Белоглазовой и Л.П. Кроливецкой [1], А.Н. Иванова [2] дают основание утверждать, что в экономической литературе наравне с понятием банковская услуга используется понятие банковская операция, а иногда и заменяет его.

Ряд авторов (О.И. Лаврушин [3], Е.Ф. Жуков [4]) рассматривает банковские операции как проявление банковских функций на практике, а банковскую услугу как проведение банковских операций по поручению клиента в пользу последнего за определенную плату.

Таким образом, функциональный подход сопоставляет банковскую услугу с одной или несколькими операциями банка. Его сторонники не отражают в определениях разнообразные отношения, возникающие между банком и потребителем по поводу передачи стоимости, предполагая, что банковские услуги выражаются в действиях банка.

На наш взгляд, есть необходимость разграничения понятий «услуга» и «операция». В отличие от банковской операции, которая, как правило, завершается обратной операцией (например, выдача кредита - его погашением), банковская услуга включает также совокупность сопровождающих действий, делает более эффективными взаимосвязанные операции как для банка, так и для его клиента.

Маркетинговый подход рассматривает банковскую услугу с точки зрения полезности, т.е. способности услуги удовлетворить потребности клиента. Банковскую деятельность рассматривают не с точки зрения производителя, а потребителя услуг. В рамках данного подхода дают свои определения В.Е. Хруцкий, И.В. Корнеева [5], П. Дойль [6], Васильев А.В. [7].

Представители институционального подхода (Д. Берг, С. Фишер, Р. Дорнбуш, Ф. Мишкин, К. Майер, Дж. Синки, Х.У. Дёриг, Д.С. Кидуэлл, РЛ. Петерсон, Д.У. Блэкуэлл, Э.Дж. Долан, Роде Э. и др.) обосновывают производительную роль банков. Они рассматривают банки как фирмы, которые являются производителями и поставщиками финансовых услуг, включая трансакционные, портфельные, информационные услуги [8].

В зарубежной литературе, опирающейся на достижения институционалистов, в основном говорится о «производстве банковских продуктов» или «банковских услуг», направленных на удовлетворение потребностей первичных сберегателей и инвесторов.

А.В. Яцевич [9] подходит к определению банковской услуги как составной части банковского продукта.

В заключение обзора подходов к определению банковской услуги необходимо обратить внимание на определение отечественного автора Г. О. Кузьменко [10], который обобщает вышеизложенные подходы в своей дефиниции. По мнению белорусского автора, банковская услуга представляет собой, с одной стороны, деятельность банка, направленную на удовлетворение потребностей клиентов, с другой стороны - полезный эффект, получаемый в результате этой деятельности. Понятие услуги отражает то обстоятельство, что она предоставляется и потребляется одновременно; соответственно, банковская услуга включает в себя и процесс обслуживания клиента - деятельность банка, и результат - полезный эффект.

\section{РЕЗУЛЬТАТЫ И ИХ ОБСУЖДЕНИЕ}

Существует несколько подходов к классификации спектра предоставляемых банковских услуг. И.А. Киселева подразделяет банковские услуги на специфические (тра- 
диционные) и неспецифические (нетрадиционные). Традиционными банковскими являются депозитные, кредитные и расчетные операции, к нетрадиционным операциям относят посреднические, гарантии и поручительства, доверительные и т.П. Промежуточное положение занимают дополнительные операции: валютные, операции с ценными бумагами, с золотом, драгоценными металлами и слитками [11].

С.А. Гурьянов классифицирует банковские услуги следующим образом: кредитные услуги, депозиты (юридических и физических лиц), расчетно-кассовые услуги, инвестиционные операции и ценные бумаги, трансформация ссудных капиталов (форфейтинг, факторинг, лизинг, траст и др.), консультационные и аудиторские услуги [12].

Классификация, предложенная А.В. Яцевичем заключается в разделении услуг на три вида: портфельные, транзакционные и операционные.

К портфельным услугам относятся: предоставление займов клиентам (кредиты) и прием денежных средств во вклады (депозиты). Банки аккумулируют временно свободные ресурсы в виде депозитов и распределяют их в форме кредитов. Оказывая эти услуги, банки перераспределяют ресурсы от лиц, совершающих сбережения, к лицам, нуждающимся в кредите, и тем самым обеспечивают предприятия дополнительными финансовыми ресурсами.

Вторая категория услуг - транзакционные - включает в себя услуги по обслуживанию сделок и разделяется на два типа: ведение системы расчетов, фиксирующей перемещение ценностей с соответствующим отражением в бухгалтерском учете, и проведение конверсионных операций. Транзакционные услуги непосредственно связаны с обслуживанием платежного и налично-денежного оборота.

К операционным услугам банков относятся инвестиционные, трастовые услуги, услуги по страхованию, привлечению капитала, обслуживание слияний и поглощений, брокерские услуги.

Яцевич А.В. отмечает, что деление услуг на трансакционные, портфельные и операционные носит теоретический характер. Развитие банковского дела привело к перемешиванию разных видов услуг. Сегодня банки предлагают к продаже не отдельные услуги, а пакеты услуг, получившие название «банковских продуктов». Банковский продукт обычно сочетает в себе услуги всех трех видов (трансакционные, кредитнодепозитные и операционные). Например, пластиковые карточки используются для расчетных операций, для покрытия овердрафтов по ним применяются различные депозитно-кредитные схемы, а за пользование пластиковой карточкой может взиматься комиссия как за операционную услугу [13].

Электронные банковские услуги отличаются от традиционных банковских услуг не по полезности, а по технологии удовлетворения потребностей клиента. Поэтому наряду с обладанием традиционных признаков банковских услуг (непостоянство качества услуг, договорный характер банковского обслуживания, связь банковского обслуживания с деньгами, протяженность обслуживания во времени, вторичность удовлетворяемых банковскими услугами потребностей), им присущи определенные особенности, такие как абстрактность, общедоступность, обезличенность, экстерриториальность, интерактивность обслуживания, множественность каналов доступа [14].

Специфика электронных банковских услуг требует от потребителей экономической культуры, вызывает необходимость разъяснения содержания услуги клиенту, усиливает значение фактора доверия клиентов к банковскому сектору экономики. Электронные банковские услуги основаны на формировании партнерских отношений с клиентом, оказания ему всесторонней помощи, выражающейся в полезном эффекте.

Преимущества электронных банковских услуг по сравнению с традиционными услугами заключаются в следующем:

- удобство для клиентов; 
- привлечение большего числа потребителей на рынке через разные сети телекоммуникаций;

- возможность круглосуточного предоставления услуг;

- возможность быстрой диверсификации предоставляемых услуг в условиях изменяющейся рыночной среды;

- возможность в режиме реального времени выбрать оптимальный вид услуги из предполагаемого спектра банковских продуктов.

Таким образом, электронные банковские услуги предлагают значительные выгоды, как для самих банков, так и для их клиентов. Для клиентов банка основными плюсами является экономия времени и денег. Из-за растущей конкуренции между банками клиенты получат лучшие и более эффективные финансовые услуги. Для банков с внедрением новых технологий финансовые услуги можно будет предоставлять с более низкими издержками, и расширять доступ к финансовым услугам. Внедрение технологических инноваций в банковское дело способствует росту не только банковского сектоpa, но и всей экономики [15].

В настоящий момент можно выделить три вида бизнес-моделей предоставления электронных банковских услуг:

а) гибридные банки: банки, предлагающие вдобавок к традиционным услугам электронные.

б) виртуальные банки: полностью электронные или виртуальные банки, также известные как бесфилиальные или полностью интернетизированные банки. Такие банки могут не иметь операций по вкладам и снятию наличных в банкоматах, используя для этих целей инфраструктуру других банков.

в) альянсы: стратегические партнерства, основывающиеся на конкретном опыте или имени одной организации и опыте в сфере создания новых услуг и диверсификации маркетинговой стратегии другой компании.

Как и любая другая деятельность банка, осуществление электронных услуг сопряжено с определенными рисками. Основными рисками являются стратегический, операционный, репутационный и правовой риски. Некоторые специфические проблемы пересекаются между различными категориями риска. Например, брешь в системе безопасности, обеспечивающая неавторизированный доступ к клиентской информации, может быть классифицирована как операционный риск, но в то же время, эта проблема может подвергнуть банк правовому и репутационному рискам [15].

Безопасность информационных систем считается основным операционным риском. Забота о безопасности является самым важным вопросом для многих клиентов, пользующихся электронными услугами. Экономические выгоды от обслуживания со стороны клиента теряют своё значение, если ожидаемый уровень безопасности электронных каналов низок. Обучение и предупреждение клиентов о безопасности при совершении электронных платежей могут играть значимую роль в защите потребителей и для минимизации репутационного риска. Помощь в процессе обучения и требования к банкам усилить осведомлённость клиентов могут стать основным элементом в защите прав потребителей для органов надзора.

Для более детального понимания сущности банковских электронных услуг необходимо также обозначить среду, в которой они действуют. Ею выступает электронная коммерция как часть формирующейся электронной экономики. Электронная коммерция традиционно включает в себя:

а) электронную торговлю;

б) электронное движение капитала;

в) электронный Интернет- онлайн-банкинг;

г) электронный маркетинг; 
д) электронное страхование;

е) электронные деньги;

ж) электронный обмен информацией.

Электронная торговля формирует общее впечатление об электронной коммерции и электронной экономике. Не смотря на наличие электронных денег, интернетбанкинга, постоянное обновление виртуальных продуктов, популяризацию новых технических средств коммуникации (планшетов, смартфонов), электронная торговля пока существенно уступает торговле реальной продукцией [16].

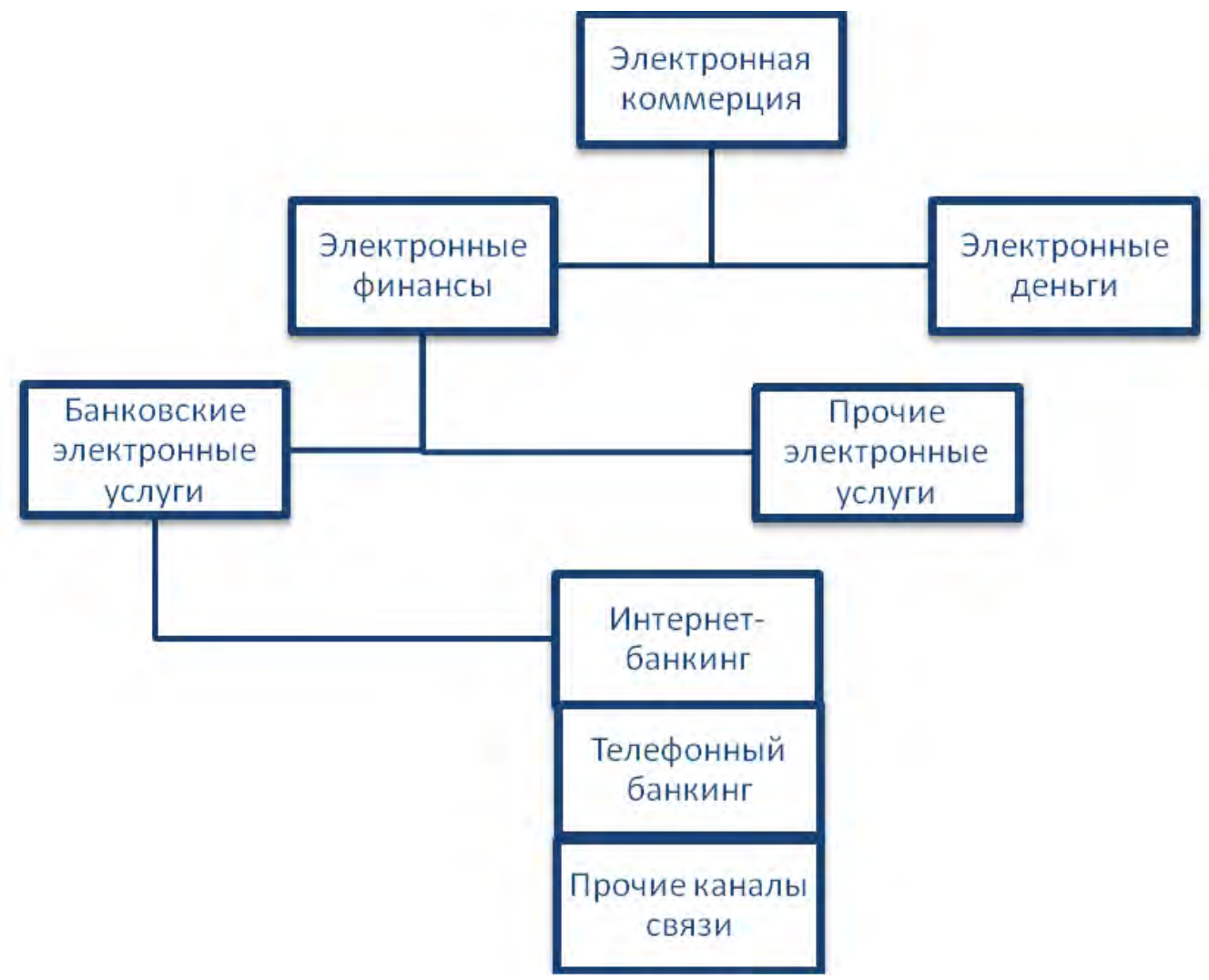

Рисунок 1 - Место банковских электронных услуг в системе электронной коммерции

Более важное место в электронной экономике занимают финансовые учреждения, которые обладают достаточной платежеспособностью для приобретения передовых информационных технологий с целью постоянной модернизации и совершенствования ведения бизнеса. Часто именно финансовые учреждения выступают двигателями развития электронной экономики (коммерции, торговли), создавая самостоятельные отрасли электронного банкинга, страхования и используя все новые технологические решения.

Таким образом, выступая составной частью электронной коммерции и электронных финансов, банковские электронные услуги отличаются от традиционных банковских услуг не по полезности, а по технологии удовлетворения потребностей клиента. Их особенностями выступают абстрактность, общедоступность, обезличенность, экстерриториальность, интерактивность обслуживания, множественность каналов доступа.

К розничным электронным банковским услугам относятся основные услуги: на базе банковских пластиковых карт, удовлетворяющие потребности в ликвидности через банкоматы с использованием электронных расчетов, а также сопутствующие услуги: запрос выписки, загрузка информации о транзакциях, предоставление и оплата счетов, прием заявки на кредит и др. 
Одной из самых популярных услуг среди розничных клиентов является интернетбанкинг. Интернет-банкинг - услуга по совершению безналичных платежей со счетов по оплате услуг, перечисления денежных средств на текущие (расчетные) и иные счета, оказание иных услуг с помощью интернет-технологий; интернет-банкинг является частью систем дистанционного банковского обслуживания.

Система дистанционного банковского обслуживания - совокупность технологий предоставления банковских услуг и осуществления банковских операций с использованием программных, технических средств и телекоммуникационных систем, обеспечивающих взаимодействие банка и клиентов, в том числе передачу клиентом в банк расчетных и иных документов в электронном виде.

Для обеспечения максимальной безопасности операций своих клиентов и конфиденциальности передаваемой по каналам связи информации банки используют технические и программные средства, а именно:

- защита системы ДБО с помощью пароля, ограничивающего доступ к системе ДБО и её подсистемам;

- шифрование электронных документов для обеспечения их защиты при возможном перехвате в каналах связи;

- применение электронно-цифровой подписи документов.

Call-центр или контакт-центр это система круглосуточной информационной поддержки клиентов банка. При обращении клиент получает информацию об услугах банка, в том числе по условиям кредитования, размещения средств в депозиты, ведения счетов, а также адреса отделений банка и режимы их работы. Клиенты банков в Беларуси могут воспользоваться не только привычными стационарным и мобильным телефонами, но и также задать вопрос on-line специалисту банка, а также посредством Еmail или Skype. Можно просматривать новости банка на страницах в Google+, Mail.ru, LiveJournal, а также в социальных сетях «Facebook», «Одноклассники», «Вконтакте» и «Twitter». Например, сайт ОАО «БПС-Сбербанка» предлагает клиентам вебинары через «WEВ контакт-ЦЕНТР» с образовательными темами.

При сравнительном анализе банков в зачет будет приниматься наличие круглосуточной системы обслуживания клиентов, что соответствует современным требованиям к качеству обслуживания. Отсутствие данного функционала может компенсироваться системами IVR.

IVR (InteractiveVoiceResponse) это система интерактивного голосового ответа, голосовых меню, при пользовании которыми абонент общается с автоматизированным звуковым интерфейсом - автоматическим информатором.

Положительные моменты системы: круглосуточное информационно-справочное обслуживание клиентов, доступность информации в любой точке мира, экономия времени. Технология уже внедрена в ОАО «Белгазпромбанк», ОАО «БПС-Сбербанк», ОАО «БНБ-Банк», «Приорбанк» ОАО, ЗАО «МТБанк», ЗАО «Альфа-Банк», ОАО «ХКБанк», ЗАО «Банк ВТБ (Беларусь)», ЗАО «Идея Банк».

В Беларуси чаще используется система «SMS-банкинг», которая дает возможность держателям карточек платежных систем БелКарт, VISA и MasterCard - владельцам мобильных телефонов осуществлять с помощью SMS-сообщений платежи в пользу производителей услуг и совершать иные операции.

Технология позволяет совершать следующие операции:

- получение информации о доступной сумме по карточке;

- совершение платежей: оплата услуг операторов мобильной связи, оплата услуг Интернет-провайдеров, оплата коммунальных услуг, оплата услуг операторов кабельного телевидения, оплата квартирного телефона, пополнение электронных кошельков, погашение кредитов, совершение иных платежей; 
- просмотр сумм задолженностей, выставленных к оплате поставщиками услуг;

- просмотр сумм задолженностей, выставленных к погашению по кредитам;

- получение справочной информации об услуге банка;

- отмена регистрации услуги «SMS-банкинг»;

- блокировка / разблокировка карточки и др.

В Республике Беларусь могут воспользоватьсяданной услугой клиенты ОАО «Белинвестбанк», ОАО «БПС-Сбербанк», ОАО «БНБ-Банк», ЗАО «Трастбанк», ЗАО «Банк ВТБ (Беларусь)», ОАО «АСБ Беларусбанк», ОАО «Паритетбанк», ОАО «Белагропромбанк», а также «Приорбанк» ОАО.

SMS-оповещение (SMS-информирование) это одна из популярных услуг, которая позволяет сразу после проведения операции по карте, а также при отмене операции или при отказе в проведении операции, получить на мобильный телефон SMS с информацией об операции, что позволяет повысить безопасность при использовании карты. Кроме того, на мобильный телефон поступают сообщения о зачислении денежных средств на карт-счет.

USSD-банкинг это система, которая предоставляется пользователям «SMSбанкинг» в сети MTC или velcom, а также в роуминге, позволяющая совершить платеж при нахождении абонента в блокировке и в случаях, когда остатка денежных средств на лицевом счете недостаточно для отправки SMS-сообщения, чтобы совершить платеж посредством SMS-банкинга.

Система позволяет:

- просмотреть баланс по карточкам, депозитам, кредитам и текущим счетам;

- переводить денежные средства между своими карточками;

- погашать кредиты и пополнять депозиты;

- оплачивать домашний и мобильный телефоны, услуги кабельного ТВ и провайдеров;

- осуществлять все услуги в системе «Расчет»;

- сменить пароль или заблокировать услугу USSD-Банк на определенный период времени.

Данный вид услуг пока что не распространен среди белорусских банков и присутствует в активе лишь 7 банков: ОАО «БПС-Сбербанк», «Приорбанк» ОАО, ОАО «Белинвестбанк», ОАО «Белгазпромбанк», ОАО «АСБ Беларусбанк», ОАО «Белагропромбанк» и ЗАО «Банк ВТБ (Беларусь)».

Более перспективной услугой представляется мобильный банкинг. Эта технология позволяет держателям банковских пластиковых карточек производить платежи и получать информацию с использованием мобильного телефона или коммуникационного устройства с GSM модулем, с установкой специального программного обеспечения.

Хотелось бы отметить разработку «IBA Мобильный банкинг» - специальное программное обеспечения, позволяющее совершать платежи и получать банковские информационные услуги посредством мобильного устройства (телефона, планшета), используя банковский карт-счет. Приложение «IBA Мобильный банкинг» для мобильных устройств является программной оболочкой для функций SMS-банкинга и предоставляет удобный интерфейс, позволяющий пользоваться услугами SMS-банкинга, не задумываясь о формате SMS-сообщений и правильности введенной информации. Данная система представлена в ОАО «Белагропромбанк», ОАО «БПС-Сбербанк» и ЗАО «Трастбанк».

Технология «Автооплата» позволяет автоматически пополнять счета абонентов MTC или velcom посредством поручения банку выполнять регулярные платежи на абонентские счета в автоматическом режиме.

«Автоматическая оплата» это сходная технология, когда банк проводит платежи по регулярным оплатам в автоматическом режиме без участия клиента. Например, ежемесячно оплачивать квартплату на основании выставленной задолженности или еженедельно пополнять счет мобильного телефона на определенную сумму. Банк вы- 
полнит платежи и проинформирует клиента о результате по электронной почте или SMS-сообщением.

ТВ-банкинг это технология, позволяющая клиентам совместно с интерактивным телевидением ZALA (РУП «Белтелеком») производить прием платежей за коммунальные услуги, услуги в пользу операторов мобильной связи, Интернет-провайдеров и иные услуги с помощью ТВ. Данная услуга не распространена широко и используется в ОАО «Белинвестбанк», «АСБ Беларусбанк» и ОАО «Белагропромбанк».

Трансфер или безналичная конверсия это возможность автоматически переводить часть зарплаты клиента в валюту (в доллары США или евро). Данный вид услуг также является новым для белорусского рынка и поставляется только ЗАО «Альфа-Банк» и «Приорбанк» ОАО.

On-line заявка на карточку это оформление банковской платежной карточки через сайт банка, посредством заполнения формы в электронном виде. Данная услуга достаточно быстро прижилась на белорусском рынке и используется у десяти банков.

On-line заявка на кредит - это оформление кредита в режиме онлайн, что значительно ускоряет получение кредита, самая популярная услуга среди банков республики.

К оптовым электронным банковским услугам относятся межбанковские электронные расчеты, локальные специальные и глобальные компьютерные сети («БанкКлиент». «Интернет-Банк-Клиент» и др.), позволяющие клиенту управлять ликвидностью, осуществлять денежные переводы, оплачивать транзакции и совершать иные операции. В Республике Беларусь к данным услугам можно отнести услуги Сообщества Всемирных Интербанковских Финансовых Телекоммуникаций (Society for Worldwide Interbank Financial Telecommunications, далее - система SWIFT), централизованной интегрированной банковской системы «SC-BANK NT», услуги РЦСОЭД, а также системы BISS.

Сообщество Всемирных Интербанковских Финансовых Телекоммуникаций (SWIFT) - находящееся в собственности банков кооперативное сообщество (глобальная автоматическая защищенная телекоммуникационная система), которое предоставляет услуги по передаче информации между финансовыми организациями и использующее единообразные стандарты форм финансовых сообщений по всему миру. Главный офис расположен в Брюсселе. В настоящий момент членами SWIFT являются более 10000 организаций, в том числе около 1000 корпораций. Каждый банк, включённый в системy, имеет свой уникальный SWIFT код. Теоретически для совершения платежа в Европе достаточно знать SWIFT код банка и IBAN код получателя. В день через SWIFT проходит более миллиона транзакций о денежных переводах, межбанковских платежах, ценных бумагах.

Централизованная интегрированная банковская система «SC-BANK NT»это совокупность программно-технических средств разработки ООО «Софтклуб», предназначенных для автоматизации банковской деятельности и отвечающих установленным требованиям, используемая в подразделениях банков.

РЦСОЭД - республиканская централизованная система обмена межбанковской корреспонденцией в форме электронных документов. Обмен межбанковской корреспонденцией осуществляется через головные банки, подключенные к РЦСОЭД. Для подключения банку или небанковской кредитно-финансовой организации необходимо заключить договор с расчетным центром РЦСОЭД. Подлинность переданной через РЦСОЭД корреспонденции удостоверяется электронной цифровой подписью.

BISS - система межбанковских расчетов Национального банка Республики Беларусь, в которой в режиме реального времени осуществляются межбанковские расчеты по срочным и несрочным денежным переводам.

Таким образом, в республике представлен достаточно широкий спектр электронных услуг, являющихся аналогами услуг, предоставляемых в зарубежных странах с 
развитой системой безналичных расчетов, однако необходимо отметить, что как разнообразие услуг, так и уровень их организации зависят, прежде всего, от окружения: то есть от развития системы безналичных расчетов.

Аспекты развития рынка электронных банковских услуг отражены в различных программных документах: Стратегия развития банковского сектора экономики Республики Беларусь на 2011-2015 годы, План совместных действий государственных органов и участников финансового рынка по развитию в Республике Беларусь системы безналичных расчетов по розничным платежам с использованием современных электронных платежных инструментов и средств платежа на 2013-2015 годы, Национальная программа ускоренного развития услуг в сфере информационно-коммуникационных технологий на 2011-2015 годы и другие.

В частности, в Стратегии развития банковского сектора Республики Беларусь на 2011-2015 годы определены, цели, задачи, стратегические направления и условия развития электронных банковских услуг в республике.

Так, в данной программе подчеркивается, что развитие информационных технологий в современной банковской системе становится одним из главных элементов стратегии развития банков, определяющих качество предоставляемых услуг, уровень менеджмента и их надежность [17].

Данной программой определены цели развития информационных технологий в банковской сфере Республики Беларусь, ими выступают:

- повышение качества и увеличение количества услуг, предоставляемых клиентам банковской системы;

- обеспечение доступности банковских услуг независимо от территориальной принадлежности клиентов;

- повышение эффективности, надежности и безопасности функционирования информационных систем.

Однако, исключительно расширение спектра услуг недостаточно для развития информационной сферы банковского бизнеса. Необходимо максимальное вовлечение клиентов как корпоративного, так и розничногосекторов. И, если юридические лица все более активно используют преимущества электронных услуг, о чем свидетельствует доля передаваемых платежных инструкций в электронном виде через систему дистанционного банковского обслуживания - по данным ряда банков она достигает 96 \%, - то активность физических лиц в использовании электронных услуг низка. Очевидно, путь экстенсивного развития не может обеспечить долгосрочного роста использования электронных инструментов [18].

В этой связи стоит обратить внимание на то, что система электронных банковских услуг находится во взаимосвязи с системами электронных финансов и электронной коммерции, схематически представленной на рисунке 1. Исследуя связи в данной модели, можно заключить, что развитие банковских услуг не может развиваться без соответствующих темпов развития электронной коммерции в стране, широкого применения электронных финансов и электронных денег.

Обобщая вышеизложенное, мы можем выделить факторы, влияющие на развитие электронных банковских продуктов:

- уровень развития платежной системы в стране;

- распространенность в стране электронной коммерции и её составляющих;

- технические и информационные возможности банков;

-заинтересованность клиентов банка в оказании услуг с применением информационных технологий.

Современное состояние рынка электронных банковских услуг республики во многом определяется направлениями, определенными в Плане совместных действий государственных органов и участников финансового рынка по развитию в Республике Беларусь системы безналичных расчетов по розничным платежам с использованием совре- 
менных электронных платежных инструментов и средств платежа на 2013-2015 годы. Он содержит концептуальные подходы к дальнейшему развитию розничных безналичных платежей и определяет результат работы - увеличение показателя доли безналичного денежного оборота в розничном товарообороте организаций розничной торговли и доли безналичного денежного оборота в объеме платных услуг населению к 1 января 2016 г. до 50 \%, а также снижение нагрузки на платежный терминал до 160 карточек [19].

Для реализации мероприятий Плана создан Межведомственный координационный совет по развитию системы безналичных расчетов, также организована работа комитета по безналичным расчетам при Ассоциации белорусских банков.

Прорабатываются различные варианты возврата банками денежных средств в случаях их несанкционированного списания с текущих (расчетных) банковских счетов держателей карточек. Расширяется спектр производителей товаров, работ и услуг, в пользу которых можно совершать платежи с использованием автоматизированной информационной системы «Единое расчетное и информационное пространство». Национальный банк постоянно изучает предложения поставщиков новых технологий в сфере осуществления безналичных платежей [20].

Поскольку основная проблема, замедляющая развитие применения электронных услуг в республике, это низкая активность населения в данном направлении, то особый интерес в анализе состояния рынка электронных услуг вызывает розничный бизнес. Данная проблема послужила основанием для создания Государственной программы развития в Республике Беларусь системы безналичных расчетов по розничным платежам с использованием электронных платежных инструментов и средств платежа на 2012-2015 годы, среди целей которой выделяют повышение качества обслуживания населения. Без достаточного вовлечения физических лиц в сферу электронных услуг её рост невозможен, количество операций выступает своеобразным ограничителем.

В настоящее время основными секторами, определяющими рост сферы электронных операций, названы сектора банковских платежных карт, электронных денег и систем дистанционного банковского обслуживания [21].

Банковская платежная карточка по-прежнему является основным платежным инструментом у населения для проведения безналичных платежей.

Эквайринг по операциям в организациях торговли и сервиса осуществляют 8 банков. Процессинг банковских платежных карточек на территории Республики Беларусь осуществляют: ОАО «Банковский процессинговый центр», «Приорбанк» ОАО, ОАО «Банк БелВЭБ», ОАО «Белинвестбанк» и ЗАО «МТБанк». ОАО «Белгазпромбанк» приступил к созданию собственного процессингового центра на территории Республики Беларусь. ОАО «ХКБанк» и ЗАО «Банк ВТБ (Беларусь)» пользуются услугами процессинговых центров-нерезидентов.

Одним из важных ключевых параметров развития рынка банковских платежных карточек является эмиссия кредитных карт. Основной объём эмиссии в республике приходится в настоящее время на карты, эмитируемые в рамках зарплатных проектов, когда карта выступает в качестве инструмента для выплаты заработной платы сотрудникам организаций корпоративных клиентов банка. Эмиссия кредитных карт позволяет банкам выйти на новый уровень развития, при небольших уровнях операционных затрат привлекая новые клиентские группы. 


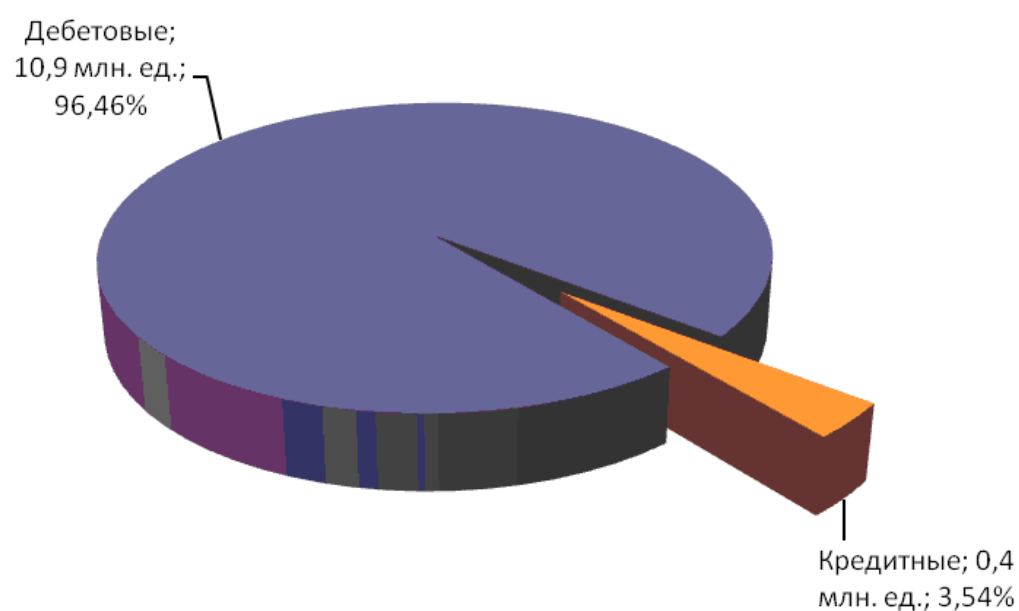

Рисунок 2 - Данные о находящихся в обращении банковских платежных карточках на 01.01.2013, млн. ед.

Примечание -Источник [22]

Как следует из приведенных на рисунке 2 данных, в Республике Беларусь подавляющее большинство находящихся в обращении карточек являются дебетовыми. Это расходится с тенденцией в развитых странах, где доля кредитных карточек существенно выше.

Таблица 1 - Данные о находящихся в обращении банковских платежных карточках в Республике Беларусь и зарубежных странах по состоянию на 01.01.2013

\begin{tabular}{|c|c|c|c|c|c|}
\hline \multirow{2}{*}{ Государство } & \multicolumn{2}{|c|}{ Дебетовые карты } & \multicolumn{2}{|c|}{ Кредитные карты } & Всего карт в \\
\cline { 2 - 4 } & $\begin{array}{c}\text { Количество, } \\
\text { млн. ед. }\end{array}$ & $\begin{array}{c}\text { Удельный } \\
\text { вес, \% }\end{array}$ & $\begin{array}{c}\text { Количество, } \\
\text { млн. ед. }\end{array}$ & $\begin{array}{c}\text { Удельный } \\
\text { вес, \% }\end{array}$ & $\begin{array}{c}\text { облении, ед. } \\
\text { млн }\end{array}$ \\
\hline Беларусь & 10,9 & 96,46 & 0,4 & 3,54 & 11,3 \\
\hline Россия & 180,0 & 90,00 & 20,0 & 10,00 & 200,0 \\
\hline Украина & 26,7 & 74,37 & 9,2 & 25,63 & 35,9 \\
\hline Чехия & 8,1 & 78,64 & 2,2 & 21,36 & 10,3 \\
\hline Финляндия & 7,0 & 61,95 & 4,3 & 38,05 & 11,3 \\
\hline Швеция & 10,9 & 53,96 & 9,3 & 46,04 & 20,2 \\
\hline Германия & 104 & 79,63 & 26,6 & 20,37 & 130,6 \\
\hline
\end{tabular}

Примечание - Источник[22]

По данным таблицы 1 можно заключить, что доля кредитных карт в обращении может служить в определенной степени индикатором развития системы безналичных расчетов с использованием банковских платежных карт.

Таким образом, необходимо обратить внимание на совершенствование и продвижение данного инструмента в Республике Беларусь, а также выявить причины низких темпов эмиссии кредитных карт и принять меры для стимулирования их выпуска. Предполагаемой причиной доминирования дебетовых карт на рынке республики может быть масштабный выпуск дебетовых карт национальной платежной системы БЕЛКАРТ. Однако стоит отметить, что данная тенденция может быть связана не только с объемной эмиссией карт данного типа, но и с низкой финансовой грамотностью населения.

Вторым по значимости развития безналичных платежей в Республике Беларусь является сектор электронных денег.

В Республике Беларусь функционирует 9 систем электронных денег, эмитентами которых являются 8 белорусских банков. Выпускаемые в обращение электронные деньги используются для оплаты товаров (работ, услуг), в том числе в сети Интернет, посредством каналов связи, предоставленных мобильными операторами, и через устройства по приему наличных денег (устройства cash-in) для оплаты топлива и сопутствующих това- 
ров на автозаправочных станциях. Растет также количество частных переводов электронных денег между держателями.

Третьим по значимости направлением увеличения доли безналичных расчетов является активное развитие банками систем дистанционного обслуживания. В 2014-2015 гг. услуги систем дистанционного банковского обслуживания предоставляли почти все банки-эмитенты, в том числе:

а) интернет-банкинг - 20 банков (общее количество клиентов, подключенных к данной услуге, около 1 млн. чел.);

б) мобильный банкинг - 16 банков (клиентов свыше 175 тыс. чел.);

в) СМС-банкинг - 10 банков (клиентов более 1 млн. чел.);

г) ТВ-банкинг - 3 банка (клиентов более 3 тыс. чел.).

Наиболее распространенной услугой на данный момент выступает онлайн-заявка на кредит - её использует 21 банк из двадцати пяти. В данной услуге заинтересован банк, поскольку это позволяет сократить операционные расходы и обеспечить приток клиентов, упростив процедуру оформления кредита. Второй по популярности услугой является интернет-банкинг, им располагают 20 банков. В настоящее времени предоставление данной услуги стало необходимым элементом розничного бизнеса на белорусском рынке наряду с услугой sms-оповещения, которую предоставляет 19 банков из двадцати пяти. Наименее распространенными являются услуги автооплаты, а также трансфера и ТВбанкинга: их предоставляют менее 5 банков республики. Необходимо подчеркнуть, что клиенты лишь пяти банков Беларуси имеют возможность круглосуточной поддержки call-центра: гораздо больший интерес у банков вызывает система IVR, используемая у десяти банков. Стоит отметить, что всё больше банков объявляют о поддержке мобильных устройств в системе дистанционного обслуживания -шестнадцать банков имеют в своем активе услугу мобильного банкинга. Данный факт особенно важен при внедрении системы безналичных расчетов с использованием мобильных устройств.

Наиболее развит сектор электронных услуг у банков ОАО «БПС-Сбербанк», «Приорбанк» ОАО, ОАО «Белинвестбанк», ОАО «Белагропромбанк» и ЗАО «Банк ВТБ (Беларусь)». Наибольшее количество услуг оказывают Приорбанк и БПС-Сбербанк 10 электронных услуг. Безусловно, количество услуг не может выступать оценкой степени развития сектора дистанционного обслуживания, однако, как правило, именно банки с широким спектром электронных услуг привносят инновации в банковскую сферу. Стоит отметить, что решающую роль в лидировании на рынке электронных услуг играет наличие собственного центра разработок, также сотрудничество с партнерами-разработчиками.

Доля иностранного капитала играет не последнюю роль. Также, для реализации сложных IT-проектов нужны специалисты, это достаточно дорогие специалисты и оплата их труда не каждому банку под силу. Поэтому лидерами являются банки, которые включены в крупную международную банковскую сеть, где уже существуют собственные разработки и центры подготовки специалистов. В основном, новые технологии попадают в республику именно через такие банковские сети.

Таким образом, рынок электронных банковских услуг Республики Беларусь находится в стадии развития. Вследствие тесной взаимосвязи с развитием платежных систем и безналичных расчетов, необходимо продолжать политику поддержки развития электронных платежных инструментов, повышения финансовой грамотности населения, а также обеспечения банками клиентов организационно-техническими средствами передачи финансовой информации. 


\section{ВЫВОДЫ}

Итак, можно отметить, что в экономической литературе отсутствует единое определение банковской услуги. Существуют различные подходы к определению понятия «банковская услуга» и «банковский продукт», освещающие данные категории с маркетинговой, функциональной и институциональной точек зрения.

Выступая составной частью электронной коммерции и электронных финансов, банковские электронные услуги отличаются от традиционных банковских услуг не по полезности, а по технологии удовлетворения потребностей клиента. Их особенностями выступают абстрактность, общедоступность, обезличенность, экстерриториальность, интерактивность обслуживания, множественность каналов доступа.

Целесообразно подчеркнуть тот факт, что рынок электронных банковских услуг Республики Беларусь находится в стадии развития. Вследствие тесной взаимосвязи с развитием платежных систем и безналичных расчетов, необходимо продолжать политику поддержки развития электронных платежных инструментов, повышения финансовой грамотности населения, а также обеспечения банками клиентов организационнотехническими средствами передачи финансовой информации.

В Республике Беларусь наблюдаются попытки расширения сферы электронной коммерции и применения электронных денег, что оказывает непосредственное влияние на развитие электронных банковских услуг. При сохранении данной тенденции применение современных информационных технологий в банковской сфере станет обязательным условием осуществления деятельности.

\section{ЛИТЕРАТУРА}

1. Банковское дело: учебник / Г.Н. Белоглазова [и др.]; под общ. ред. Г.Н.Белоглазовой, Л.П. Кроливецкой. - Санкт-Петербург: Финансы и статистика, 2003. $-592 \mathrm{c}$.

2. Иванов, А.Н. Банковские услуги: зарубежный и российский опыт / А.Н. Иванов. - М.: Финансы и статистика, 2002. - 176 с.

3. Банковское дело / О.И. Лаврушин [и др.]; под ред. О.И. Лаврушина. - М.: Финансы и статистика, 2007. - 576с.

4. Банки и банковские операции: Учебник для вузов / Е.Ф. Жуков [и др.]; под ред. Е.Ф. Жукова - М.: Банки и биржи, 2008. - 527 с.

5. Хруцкий, В.Е., Корнеева, И.В Современный маркетинг / В.Е. Хруцкий, И.В Корнеева - М.: Финансы и статистика, 2001. - 207 с.

6. Дойль, П. Маркетинг - менеджмент и стратегии / П. Дойль; пер. с англ.; под ред. Ю.Н. Каптуревского. - СПб.: ЭКСМО, 2004. - 480 с.

7. Васильев, А.В. Формирование системы менеджмента качества кредитной организации / А.В. Васильев, Е.Б. Герасимова; под. ред. Б.И. Герасимова. - Тамбов: Изд-во Тамб. Гос. Техн. Ун-та, 2005. - 92 с.

8. Парусимова, Н.И. Банковское дело: модель развития / Н.И. Парусимова - М.: Московская Академия предпринимательства, 2005. - 495 с.

9. Яцевич, А.В. Возможности Интернет для рынка банковских услуг / А.В. Яцевич. - М.: Банки и биржи, 2004. - 175 с.

10. Кузьменко, Г. О содержании понятия «Банковская услуга» / Г. Кузьменко // Вестник ассоциации белорусских банков. - 2004. - № 1-2. - С. 20.

11. Киселева, И.А. Коммерческие банки: модели и информационные технологии в процедурах принятия решений / И.А. Киселева - М.: Инфра-М. 2009. - 212c. - С. 52.

12. Гурьянов, С.А. Эффективность бизнес-коммуникаций на рынке банковских услуг: Учебное пособие / С.А. Гурьянов. - СПб.:СПбГУЭФ, 2000. - 256 с. - С. 25. 
13. Яцевич, А.В. Возможности Интернет для рынка банковских услуг / А.В. Яцевич. - М.: Банки и биржи, 2004. - 175 с. - С. 31.

14. Резник, И.А. Развитие электронных банковских услуг: автореф. дис. ... канд. экон. наук: 08.00.10 / И.А. Резник; Орен. гос. универ. - СПб., 2008. - 19 с.

15. Соколов Д.А. Управление рисками электронных банковских услуг (на примере Эстонии): автореф. дис. ... канд. экон. наук: 08.00.10 / Д.А. Соколов; СПб. гос. универ. эконом. и фин. - СПб., 2009. - 19 с.

16. Рудый, К. Электронная экономика государства / К. Рудый // Банковский вестник. - 2013. - №13. - с. 33 - 39.

17. Стратегия развития банковского сектора экономики Республики Беларусь на 2011 - 2015 годы: одобр. Правл. Нац. банка Респ. Беларусь 03.03.2011: текст по состоянию на 1 мая 2014 г. / Информационная база данных нормативно-правовых актов «Консультант-плюс».

18. Унгур, Д. Эволюция платежных систем / Д. Унгур // Банковский вестник. 2013. - №4. - с. 55 - 63. - С. 55.

19.О предложениях по развитию расчетов с использованием электронных денег: письмо Национального банка Республики Беларусь от 17 февраля 2014 г. № 77-24/62: текст по состоянию на 1 мая 2014 г. / Информационная база данных нормативноправовых актов «Консультант-плюс».

20. Маманович, П. Банковский ритейл в Беларуси: состояние и перспективы развития / П. Маманович // Банковский вестник. - 2014. - № 1. - с. 3 - 9.

21. Краснов, Ю.Е. О ходе выполнения Плана совместных действий государственных органов и участников финансового рынка по развитию в Республике Беларусь системы безналичных расчетов по розничным платежам с использованием современных электронных платежных инструментов и средств платежа на 2013-2015 годы / Ю.Е. Краснов // Банковский вестник. - 2013. - № 20. - с. 10 - 14.

22. Treasury Management Profiles [Electronic resource]/ HSBC Global Connections. - London, 2014. - URL: https://globalconnections.hsbc.com/us/en/tools-data/treasurymanagement-profiles. Date of access: 01.05.2014.

Статья поступила в редакциию 17 октября 2015 года. 